Krzysztof Stefański

Instytut Historii Sztuki, Uniwersytet Łódzki

ORCID: 0000-0002-9686-7463

\title{
Prace Konstantego Wojciechowskiego przy katedrze we Włocławku a koncepcja „stylu wiślano-bałtyckiego”
}

DOI: https://doi.org/10.26881/porta.2020.19.15

Katedra we Włocławku pw. Wniebowzięcia Najświętszej Marii Panny to jedna z najważniejszych świątyń gotyckich na nizinnych ziemiach północnej części dawnego Królestwa Polskiego. Pozostaje jednak w cieniu katedr w Poznaniu i Gnieźnie jako budowla skromniejsza w skali i mniej wartościowa artystycznie. Adam Miłobędzki stwierdził, że „mimo »katedralnych « aspiracji w ukształtowaniu naw, posiada układ większej kolegiaty czy kościoła klasztornego"', a Szczęsny Skibiński pisał o niej jako o budowli „w szeregu polskich katedr stojącej nieco na uboczu"2. Dopiero niedawno budowla doczekała się bardziej szczegółowej analizy, która uwidoczniła interesujące związki jej architektury z terenami górnoreńskimi ${ }^{3}$. Doceniono także klasę znajdujących się w świątyni czternastowiecznych witraży ${ }^{4}$. Ważnym zagadnieniem związanym $\mathrm{z}$ historią świątyni jest jej restauracja, przeprowadzona pod koniec XIX w. ${ }^{5}$ Miała ona istotny wpływ na ukształtowanie się form „stylu wiślano-bałtyckiego", dominującego w architekturze sakralnej przełomu XIX i XX w. na ziemiach zaboru rosyjskiego ${ }^{6}$.

Świątynię zaczął budować w 1340 r. biskup włocławski, Maciej z Gołańczy, a Jan Długosz z uznaniem napisał, że „wzniósł [on] nakładem wielkich kosztów piękny, nowy kościół godny miana katedry"7. Wbrew tym słowom budowa była kontynuowana jeszcze długo po śmierci biskupa (1368). Katedrę zaś konsekrowano w $1411 \mathrm{r}$.

Adam Miłobędzki, Zarys dziejów architektury w Polsce, Warszawa 1978, s. 80.

Szczęsny Skibiński, Polskie katedry gotyckie, Poznań 1996, s. 131-137.

Piotr Pajor, Joanna Utzig, „Godny miana katedry”. O genezie formy architektonicznej kościoła katedralnego we Włocławku, „Folia Historiae Artium. Seria Nowa” 2016, t. 14, s. 17-34.

4 Joanna Utzig, Witraże w katedrze we Włocławku w kontekście stylu malarstwa południowoniemieckiego pierwszej połowy XIV wieku, „Folia Historiae Artium. Seria Nowa” 2015, t. 13, s. 5-32.

5 Jerzy Frycz, Restauracja i konserwacja zabytków architektury w Polsce w latach 1795-1918, Warszawa 1975, s. 170-178.

6 Krzysztof Stefański, Polska architektura sakralna w poszukiwaniu stylu narodowego, Łódź 2000 , s. $46-60$.

7 Jan Długosz, Roczniki, czyli kroniki sławnego Królestwa Polskiego, ks. 9, 1300-1370, przeł. Julia Mrukówna, Warszawa 1975, s. 270. 
po ukończeniu korpusu nawowego w obecności króla Władysława Jagiełły. Prace przy budowie świątyni trwały jeszcze do początku XVI w., w 1526 r. zwieńczono północną wieżę. Ś Swiątynia prezentuje układ z trójnawowym, pięcioprzęsłowym korpusem o układzie bazylikowym. Trójprzęsłowe długie prezbiterium zamknięte jest wielobocznie, a ujęte niskimi aneksami bocznymi. Konstrukcja budowli charakteryzuje się ograniczonym zastosowaniem łuków przyporowych (obecnie zachowane dwa, pozostałe zniesione $)^{9}$, co uważa się za uproszczoną wersję systemu filarowo-przyporowego. Ceglane elewacje nawy głównej i naw bocznych są ujęte przyporami. We wnętrzu, zarówno w nawach korpusu, jak i w prezbiterium, zastosowano sklepienia gwiaździste. Architektura włocławskiej katedry łączy w sobie wpływy zachodnioeuropejskie i ceglanego gotyku północnych ziem polskich, wykazującego duże zależności do architektury sakralnej Pomorza i - szerzej - ziem Pobrzeża Bałtyckiego ${ }^{10}$.

Do korpusu świątyni dobudowano z dwóch stron kaplice na planie kwadratu - Najświętszej Marii Panny i św. Kazimierza, które przebudowano na początku XVII w., przykrywając kopułami. Charakterystyczny wygląd nadało świątyni przekształcenie w tym samym stuleciu partii frontowej, której dwie niewysokie wieże nakryto cebulastymi barokowymi hełmami ${ }^{11}$ (il. 1).

W XIX w. świątynia była w złym stanie i podjęto decyzję o jej restauracji. Była to inicjatywa biskupa Wincentego Popiela, pełniącego tę funkcję od $1875 \mathrm{r}$., który już trzy lata później podjął prace, rozpoczynając od renowacji kaplicy Najświętszego Sakramentu (Cibavit) i remontu więźby dachowej nad prezbiterium $^{12}$. Zamierzenia były jednak znacznie większe. Biskup postanowił dokonać gruntownej przebudowy fasady, tak by nadać jej kształt gotycki, co było zgodne $\mathrm{z}$ tendencjami panującymi w tym okresie na ziemiach polskich, odzwierciedlającymi idee rozpowszechnione w Europie przez francuskiego architekta i konserwatora zabytków, Eugène'a E. Viollet-le-Duca ${ }^{13}$.

8 Michał Morawski, Monografia Włocławka (Włocławia), Włocławek 1933, s. 202-204; Marek Machowski, Andrzej Włodarek, Włocławek. Kościół katedralny pw. Panny Marii [w:] Architektura gotycka w Polsce, t. 2, Katalog zabytków, red. Teresa Mroczko, Marian Arszyński, Warszawa 1995 (Dzieje sztuki polskiej, 2), s. 258-259; Anna Błażejewska, Elżbieta Pilecka, Dzieje sztuki [w:] Dzieje diecezji włocławskiej, t. 1, Średniowiecze, red. Andrzej Radzimiński, Włocławek 2008, s. 172.

9 Pajor, Utzig, „Godny miana katedry”..., s. 22.

10 Machowski, Włodarek, Włocławek. Kościół katedralny..., s. 259 n. Ostatnio wskazuje się także na inne źródła inspiracji, m.in. architekturą górnoreńską, zob. Pajor, Utzig, „Godny miana katedry"..., s. 33-34.

11 Kazimierz Jung, Katedra Włocławska. Krótki rys historyczny m. Włocławka, katedry i Diecezyi Włocławskiej, Włocławek 1900, s. 22-44; Morawski, Monografia Włocławka..., s. 204-209.

12 Jung, Katedra Włocławska..., s. 45; Stanisław Chodyński, Bazylika katedralna we Włocławku, „Kronika Diecezji Włocławskiej” 1929, t. 23, s. 115-116. Prace rozpoczęto od kaplicy Zwiastowania Najświętszej Marii Pannie, zob. Dariusz Lewandowski, Regotycyzacja katedry we Włocławku w końcu XIX wieku, „Studia Włocławskie” 2002, t. 5, s. 369-370.

13 Frycz, Restauracja i konserwacja..., s. 135-188; idem, Neogotyk i restauracja zabytków w Polsce [w:] Sztuka 2. połowy XIX wieku. Materiały Sesji Stowarzyszenia Historyków Sztuki. Łódź, listopad 1971, Warszawa 1973, s. 173-182. 


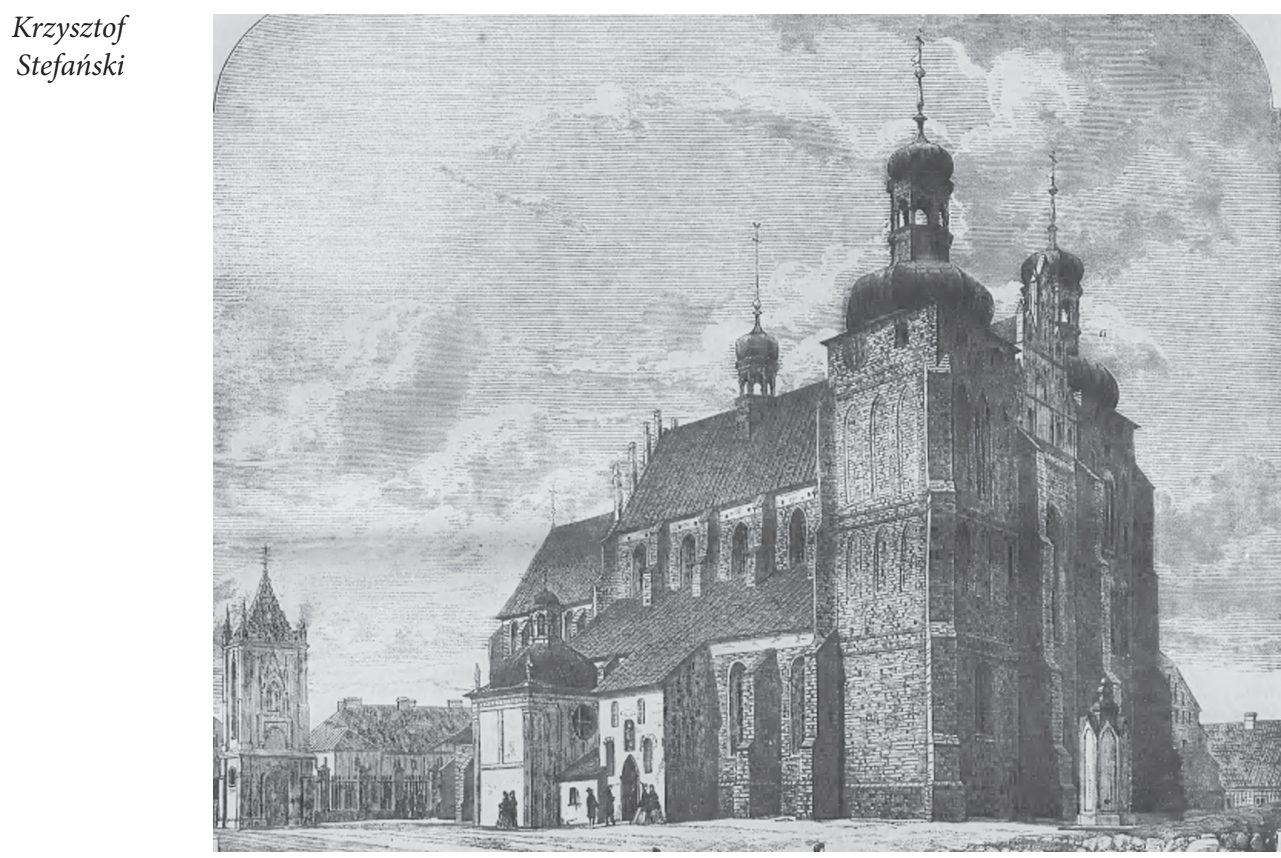

Il. 1. Adolf Kozarski, katedra we Włocławku, widok od strony północno-zachodniej, drzeworyt, repr. za: „Kłosy” 1868, t. 6, nr 148, s. 241

Biskup korzystając z rady swojego brata, Pawła Popiela, wieloletniego konserwatora zabytków Galicji Zachodniej, poprosił o wykonanie projektów krakowskiego architekta, Tadeusza Stryjeńskiego. Głównym elementem podjętych działań miała być likwidacja barokowych hełmów wież frontowych i zastąpienie ich neogotyckimi. W latach 1881-1883 Stryjeński wykonał dwie wersje planów - jedna zakładała nadbudowę wież o podstawie czworobocznej, druga - o podstawie ośmiobocznej, nakrytych iglicowymi, smukłymi hełmami. U ich podstawy znalazły się trójkątne szczyty ${ }^{14}$ (il. 2). Jednak w trakcie realizacji pojawiły się problemy natury technicznej, odkryto też spękania murów i prace przerwano ${ }^{15}$. W proces renowacji włączył się wówczas architekt warszawski, Konstanty Wojciechowski, któremu powierzono stanowisko architekta diecezji kujawsko-kaliskiej ze stolicą biskupią we Włocławku ${ }^{16}$.

14 Archiwum Archidiecezjalne we Włocławku, fotokopie drugiej wersji projektów T. Stryjeńskiego, bez sygn. (zbiór nieuporządkowany, oryginały zaginęły); Władysław Łuszczkiewicz, Katedra Włocławska i projekt p. Stryjeńskiego jej restauracyi, „Czasopismo Techniczne” 1883, nr 5, s. 56-59; nr 6, s. 69-73; zob. też Frycz, Restauracja i konserwacja..., s. 180; Jung, Katedra Włocławska..., s. 46.

15 Ibidem, s. 46-47; Konstanty Wojciechowski, Polemika w sprawie starych budynków. O restauracji katedry włocławskiej, „Tygodnik Ilustrowany” 1902, nr 43, s. 857.

16 Stanisław Chodyński, Bazylika katedralna we Włocławku, „Kronika Diecezji Kujawsko-Kaliskiej” 1919, t. 13, s. 45-46; Kazimierz Broniewski, Konstanty Wojciechowski † (Wspomnienie pośmiertne), „Przegląd Techniczny” 1911, nr 1, s. 11-12. 


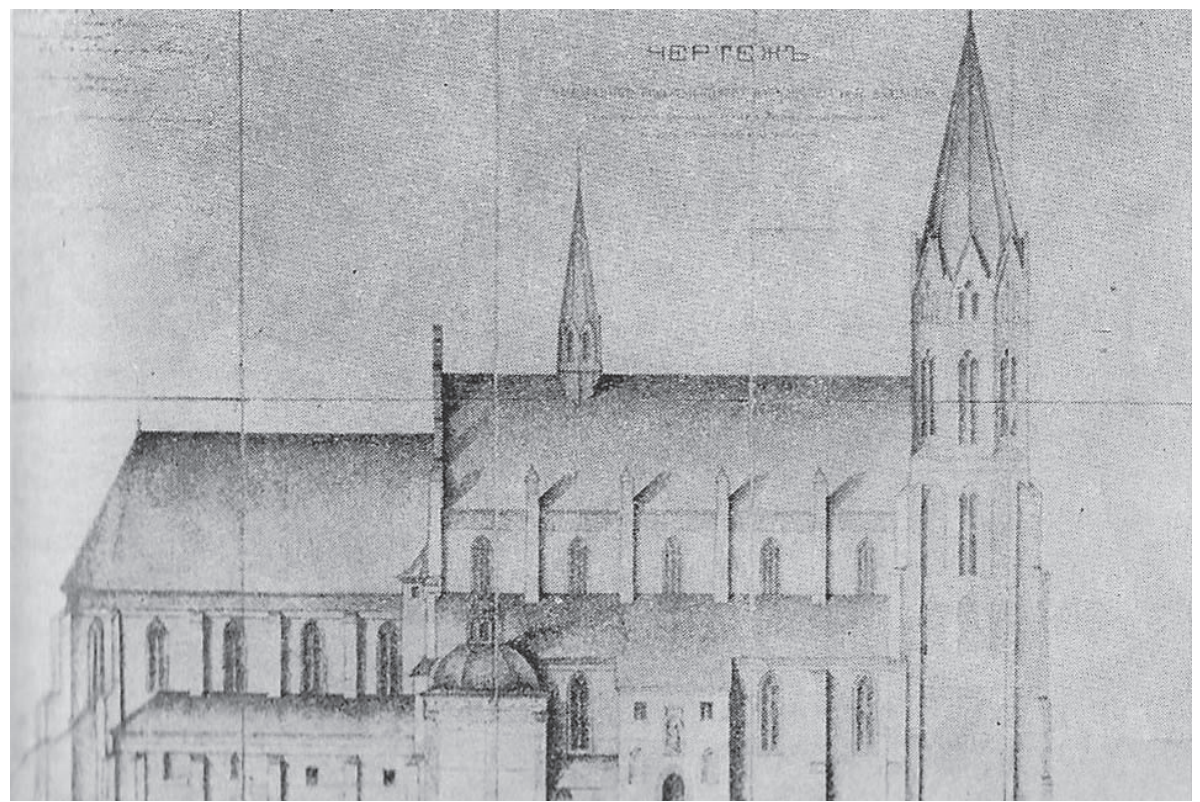

Il. 2. Tadeusz Stryjeński, projekt restauracji katedry we Włocławku, elewacja północna, 1884, Archiwum Diecezjalne we Włocławku, bez sygn.

Wojciechowski, urodzony w 1841 r. w Wojsławicach na Lubelszczyźnie, studiował na Wydziale Architektonicznym Warszawskiej Szkoły Sztuk Pięknych aż do jej zamknięcia przez władze carskie w 1862 r. Następnie wziął udział w powstaniu styczniowym, a po jego upadku kontynuował naukę w Szkole Głównej. Wykształcenie uzupełnił w Paryżu i Monachium ${ }^{17}$. Architekt szybko skierował swoje zainteresowania w stronę budownictwa sakralnego. Jego pierwszą ważną realizacją był kościół pw. św. Lamberta w Radomsku, wzniesiony w latach 1869-1876 w miejscu starego (przy wykorzystaniu planów renowacji obiektu autorstwa Wacława Berenta). Jest to budowla w stylu neobarokowym z efektowną, trójwieżową fasadą ${ }^{18}$. Wkrótce Wojciechowski zwrócił się w stronę form gotyckich, co było zgodne z ogólną tendencją panującą wówczas w polskiej architekturze sakralnej ${ }^{19}$. W tym duchu wykonał plany skromnego jednonawowego kościoła w Zerżnie koło Warszawy z lat 1881-1883 (obecnie Zerzeń w granicach miasta ${ }^{20}$. Powierzenie architektowi stanowiska archi-

Ibidem; Stanisław Łoza, Architekci i budowniczowie w Polsce, Warszawa 1956, s. 333.

18 Romuald Hube, Kościół parafialny stary i nowy w Radomsku, Warszawa 1876, s. 59-68.

19 Andrzej Majdowski, Nurt narodowy w architekturze sakralnej Królestwa Polskiego od drugiej połowy XIX wieku. Wybrane problemy, Kraków 1985 („Nasza Przeszłość. Studia z dziejów Kościoła i kultury katolickiej w Polsce”, t. 64), s. 28-43; Stefański, Polska architektura..., s. 29.

20 Konstanty Wojciechowski, Projekt kościoła parafialnego we wsi Zerżno, powiecie warszawskim, „Przegląd Techniczny” 1881, z. 10, s. 71, tabl. XIII-XV; Muzeum Narodowe w Warszawie, Rys. Pol. 15056. 


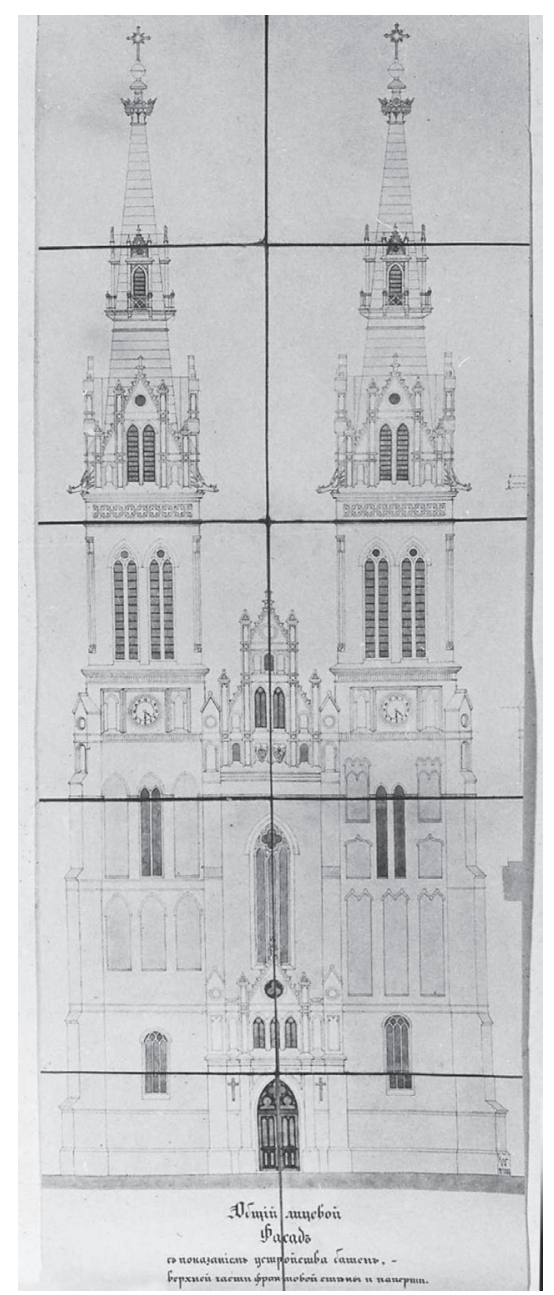

Il. 3. Konstanty Wojciechowski, projekt restauracji katedry we Włocławku, fasada, 1886, Archiwum Diecezjalne we Włocławku, bez sygn. tekta obszernej diecezji kujawsko-kaliskiej i podjęcie się przez niego renowacji gotyckiej katedry umocniły jego zainteresowanie tymi formami stylowymi. Wojciechowski wykorzystał prace przy katedrze jako okazję do rozwinięcia motywów gotyckich w dużej skali. W 1886 r. wykonał własny projekt, powracając do odrzuconej wcześniej alternatywnej koncepcji wież czworobocznych Stryjeńskiego (co konsultował z Łuszczkiewiczem). Wprowadził bardziej rozbudowany portal oraz bogatszy detal. Zaprojektował także nowy, bardziej wyniosły szczyt schodkowy pomiędzy wieżami, a ostrosłupowe hełmy wież ujął z czterech stron szczytami ${ }^{21}$. Zamierzenia te zrealizowano w ciągu następnych lat ${ }^{22}$ (il. 3).

Od 1891 r. Wojciechowski sprawował bezpośredni nadzór nad pracami - rozpoczęła się wówczas restauracja korpusu nawowego katedry, a ponadto kontynuowano regotycyzację budowli, co wiązało się m.in. z przebudową późnorenesansowych kaplic oraz przekształceniem wnętrz wraz z kształtem okien. Dawną siedemnastowieczną sygnaturkę przeniesiono, a na jej miejscu ustawiono smukłą, neogotycką ${ }^{23}$. Główną część prac ukończono w listopadzie 1893 r., oddając świątynię do użytku po dwuletniej przerwie. Uroczystej konsekracji dokonano 10 maja 1896 r. ${ }^{24}$ (il. 4). Jednak prace trwały jeszcze z przerwami do początku $\mathrm{XX}$ w. i wywoływały wiele kontrowersji oraz prasowych polemik w czasie, gdy następowała weryfikacja dziewiętnastowiecznych zasad konserwatorskich $^{25}$. W polemikę włączył się m.in. znaczący

21 Archiwum Diecezjalne we Włocławku, fotokopie projektów K. Wojciechowskiego, bez sygn. (zbiór nieuporządkowany, oryginały zaginęły); Jung, Katedra Włocławska..., s. 47.

22 Ibidem, s. 47-56; Lewandowski, Regotycyzacja katedry..., s. 371-175.

23 Jung, Katedra Włocławska..., s. 46.

24 Ibidem, s. 57-58; Stanisław Chodyński, Kościół katedralny we Włocławku (Z powodu jego konsekracji d. 10 maja r. b.), „Przegląd Katolicki” 1896, nr 22, s. 337-339; nr 24, s. 369-372; nr 25, s. 386-389.

25 Stanisław Tomkowicz, Tadeusz Stryjeński, Zygmunt Hendel, Sławomir Odrzywolski, W sprawie starych budynków, „Tygodnik Ilustrowany” 1902, nr 41, s. 802; eidem, W odpowiedzi pp. Wojciechowskiemu i Szyllerowi w sprawie starych budynków, „Tygodnik Ilustrowany” 1902, nr 52, s. 1035-1036; Wojciechowski, Polemika w sprawie starych..., s. 856-857; Stefan Szyller, 


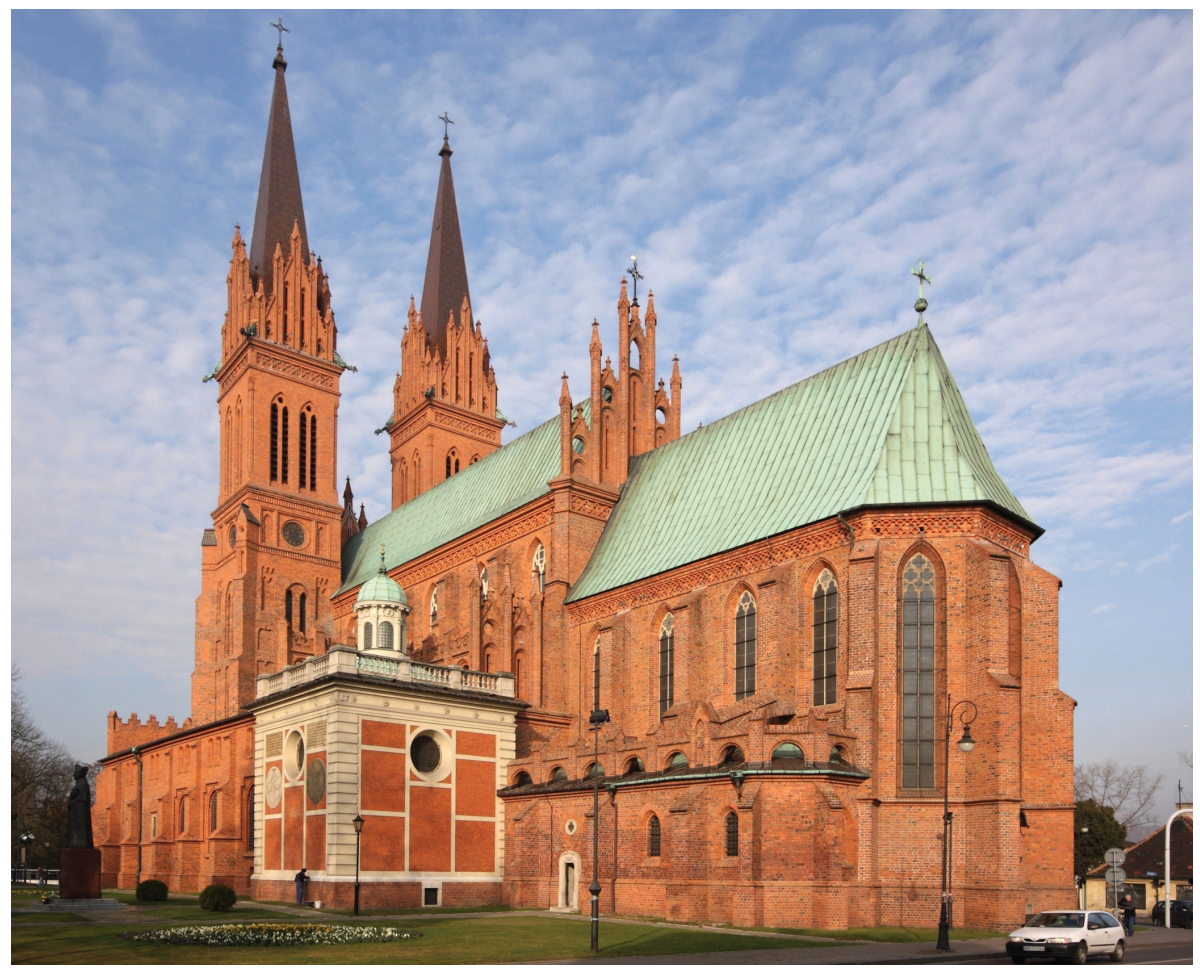

Prace

Konstantego Wojciechowskiego...

Il. 4. Katedra we Włocławku, widok od strony prezbiterium, repr. za: Wikimedia Commons, 2009

twórca tej epoki - Stefan Szyller, prowadzący prace przy katedrze w Płocku ${ }^{26}$. Wojciechowski bronił przeprowadzanych przez siebie zabiegów, podkreślając ich celowość i dążenie do zachowania pierwotnych cech budowli: „Całe wnętrze, nienaruszone, odnowiono. Prezbiterium, dzieło biskupa Golanczewskiego, stanowiące pierwotnie katedrę, odrestaurowano wiernie według zachowanych tamże motywów ostrołuku francuskiego”, zachowano również elementy „które wskazują krzyżacki sposób budowania" ${ }^{27}$. Wojciechowski stwierdzał, że zamierzeniem był powrót do pierwowzoru z XIV w., zaś „za pierwowzór należy uznać ten, który był pierwotnie, nie zaś późniejszy z epoki upadku sztuki”, czyli z epoki nowożytnej ${ }^{28}$.

Niezależnie od oskarżeń o zbyt daleko idącą ingerencję w historyczną tkankę świątyni i eliminowanie elementów nowożytnych Wojciechowski nadał katedrze

Jeszcze w sprawie starych budynków, „Tygodnik Ilustrowany” 1902, nr 44, s. 862-864; Konstanty Wojciechowski, Stefan Szyller, Ostatnie słowo w sprawie starych budynków, „Tygodnik Ilustrowany" 1903, nr 10, s. 199.

26 Małgorzata Omilanowska, Architekt Stefan Szyller 1857-1933, Warszawa 2008, s. 179-184.

27 Wojciechowski, Polemika w sprawie..., s. 857.

28 Wojciechowski, Szyller, Ostatnie słowo..., s. 199. 
Krzysztof włocławskiej efektowną formę z wyniosłą dwuwieżową fasadą i bogatym detaStefański lem, wpisującą się w nurt ceglanej architektury gotyku pomorskiego, prezentującej - jak określił w cytowanej powyżej wypowiedzi sam architekt - „krzyżacki sposób budowania”.

Wojciechowski zaangażował się w prace przy katedrze we Włocławku w czasie, gdy na ziemiach Królestwa Polskiego triumfowała koncepcja „stylu wiślano-bałtyckiego" jako polskiego stylu narodowego w budownictwie sakralnym. Termin ten wprowadzili krakowscy badacze - Władysław Łuszczkiewicz i Józef Łepkowski - na przełomie lat sześćdziesiątych i siedemdziesiątych XIX w. ${ }^{29}$, wykorzystując badania niemieckiego architekta i badacza Augusta Essenweina, który wykazywał odrębność gotyckiej architektury Krakowa ${ }^{30}$. Pod pojęciem „stylu wiślano-bałtyckiego" rozumiano formy czerpiące z gotyckiej architektury Krakowa i Małopolski, ale także z terenów nadbałtyckich ${ }^{31}$. Termin ten promował warszawski teoretyk i krytyk sztuki Karol Matuszewski, postulując zastosowanie form ceglanego gotyku („ostrołuku”) w ówczesnej praktyce architektonicznej i krzewienie form „stylu wiślano-bałtyckiego" jako polskiego stylu narodowego. Matuszewski silnie akcentował także potrzebę wykorzystania motywów regionu nadbałtyckiego ${ }^{32}$. Zwolennikiem tej koncepcji był też w późniejszym czasie inny znaczący warszawski krytyk sztuki, Franciszek Ksawery Martynowski, który podkreślał konieczność dobrego poznania dawnych zabytków ceglanego gotyku - od „niżu bałtyckiego”, Lubeki i Wismaru, poprzez Wielkopolskę i Kujawy, aż do budowli Krakowa i Sandomierza - w celu umiejętnego ich wykorzystania w ówczesnym budownictwie sakralnym ${ }^{33}$. Wybór form gotyckich jako polskiej „formy narodowej” miał swoje głębsze konotacje ideowe. Sytuował bowiem Polskę jednoznacznie w kręgu chrześcijaństwa zachodniego i kultury zachodnioeuropejskiej,

29 Władysław Łuszczkiewicz, O znaczeniu $w$ dzisiejszych czasach budownictwa średniowiecznego. Kilka uwag z dziedziny sztuki [w:] Kłosy i kwiaty. Książka zbiorowa, Kraków 1869, s. 198-201; Józef Łepkowski, Sztuka. Zarys jej dziejów, zarazem podręcznik dla uczacych się i przewodnik dla podróżujacych, Kraków 1872, s. 157-160.

30 August Essenwein, Die mittelalterlichen Kunstdenkmale der Stadt Krakau, Graz 1866.

31 Majdowski, Nurt narodowy..., s. 21-24; idem, O poglądach na styl wiślano-bałtycki $w$ polskiej architekturze sakralnej XIX wieku [w:] idem, Studia $z$ historii architektury sakralnej $w$ Królestwie Polskim, Warszawa 1993, s. 39-66; Stefański, Polska architektura..., s. 23-26.

32 Karol Matuszewski, $O$ architekturze u obcych $i$ u nas. Uwagi ze stanowiska estetycznego, „Biblioteka Warszawska” 1881, t. 3, s. 75-93, s. 231-245, s. 382-405; idem, O estetycznym i dziejowym znaczeniu ostrołukowej architektury, „Inżynieria i Budownictwo” 1882, nr 1, s. 2-4; nr 3, s. 21-22; nr 4, s. 35; nr 6, s. 57-58; nr 7-8, s. 71-73; nr 9, s. 89-90; nr 10, s. 101-103, nr 11, s. 114-116; $\mathrm{nr}$ 12, s. 125-127; Andrzej K. Olszewski, Przeglad koncepcji stylu narodowego w teorii architektury polskiej przełomu XIX i XX wieku, „Sztuka i Krytyka. Materiały do studiów i dyskusji z zakresu teorii i historii sztuki, krytyki artystycznej oraz badań nad sztuką" 1956, nr 3-4, s. 289-292.

33 Franciszek Ksawery Martynowski, O stylu wiślano-bałtyckim, „Wiek” 1881, nr 51, s. 3; Olszewski, Przegląd koncepcji stylu narodowego..., s. 292-300; Bożena Wierzbicka, Franciszek Ksawery Martynowski 1848-1896. Polihistor, teoretyk restauracji zabytków, krytyk sztuki, Warszawa 1998. 
co na ziemiach zaboru rosyjskiego, poddanych zabiegom rusyfikacyjnym, miało istotne znaczenie ${ }^{34}$.

Wydarzeniem, które zdecydowało o pełnej akceptacji koncepcji „stylu [gotyku] wiślano-bałtyckiego", przynajmniej na terenie zaboru rosyjskiego, był ogłoszony w 1886 r. konkurs na kośció św. Floriana na warszawskiej Pradze ${ }^{35}$. W regulaminie konkursowym znalazło się sformułowanie: „Styl budowy ma być ostrołuczny, w odcieniu tak zwanym wiślano-bałtyckim" ${ }^{36}$. Konkurs wywołał duże zainteresowanie - zwyciężyła propozycja Józefa Piusa Dziekońskiego, którą zrealizowano w latach 1888-1894. Świątynię uznawano powszechnie za doskonałą egzemplifikację koncepcji „stylu wiślano-bałtyckiego” jako polskiego stylu narodowego w budownictwie kościelnym. Architekt powtórzył formy praskiego kościoła w kilku kolejnych świątyniach o dużej skali - w Radomiu, Białymstoku i Żyrardowie ${ }^{37}$. Entuzjazmu dla kościoła św. Floriana nie tłumił fakt, że w budowli zastosowano rozwiązania dalekie od form charakterystycznych dla budownictwa gotyckiego ziem polskich, takich jak choćby zewnętrzne łuki odporowe przerzucone ponad nawami bocznymi czy ażurowe, smukłe hełmy wzorowane na gotyckich katedrach z ziem niemieckich ${ }^{38}$. Dziekoński przyznawał, że inspiracją był dla niego m.in. wrocławski kościół św. Michała Archanioła na Ołbinie, dzieło znanego neogotycysty Alexisa Langera $\mathrm{z}$ lat $1862-1871^{39}$. A zatem na popularyzację ceglanych form neogotyckich na ziemiach polskich z pewnością miał wpływ również neogotyk niemiecki, w którym od czasu Karla Friedricha Schinkla chętnie stosowano tego typu rozwiązania, utrwalone później przez tzw. szkołę hanowerską ${ }^{40}$.

Jak już wspomniano, Wojciechowski, po krótkim zainteresowaniu motywami nowożytnymi w kościele w Radomsku, zwrócił się w stronę ceglanych form neogotyckich, co zbiegało się z rosnącą popularnością koncepcji „stylu wiślano-bałtyckiego" na ziemiach zaboru rosyjskiego. Objęcie stanowiska architekta diecezji włocławskiej i rozpoczęcie prac przy katedrze pozwoliło mu na dobre poznanie form ceglanego gotyku pomorskiego, co wykorzystywał później w bieżącej pracy projektowej. Już w 1884 r. sporządził projekt kościoła pw. św. Wawrzyńca

34 Stefański, Polska architektura..., s. 52.

35 Majdowski, Nurt narodowy..., s. 35-37; Stefański, Polska architektura..., s. 46-49.

36 Konkurs na sporządzenie szkicowego projektu kościoła dla parafii praskiej m. Warszawy, „Przegląd Techniczny” 1886, nr 11, s. 263.

${ }_{37}$ Andrzej Majdowski, Budownictwo kościelne w twórczości projektowej Józefa Piusa Dziekońskiego (1844-1927), Warszawa 1995, s. 37-39.

38 Stefański, Polska architektura..., s. 49-51.

39 Józef Dziekoński, Kościót parafialny św. Floriana na Pradze pod Warszawa, „Architekt” 1900-1901, nr 1, kol. 7-8; Agnieszka Zabłocka-Kos, Sztuka, wiara, uczucie. Alexis Langer - śląski architekt neogotyku, Wrocław 1996.

40 Na ten temat zob. Eva Börsch-Supan, Berliner Baukunst nach Schinkel 1840-1870, München 1977 (Studien zur Kunst des neunzehnten Jahrhunderts, 24); Günther Kokkelink, Die Neugotik Conrad Wilhelm Hases. Eine Spielform des Historismus, Tl. 1, 1818-1859, Hannover 1968 (Hannoversche Geschichtsblätter, NF, Bd. 22, H. 1-3). 


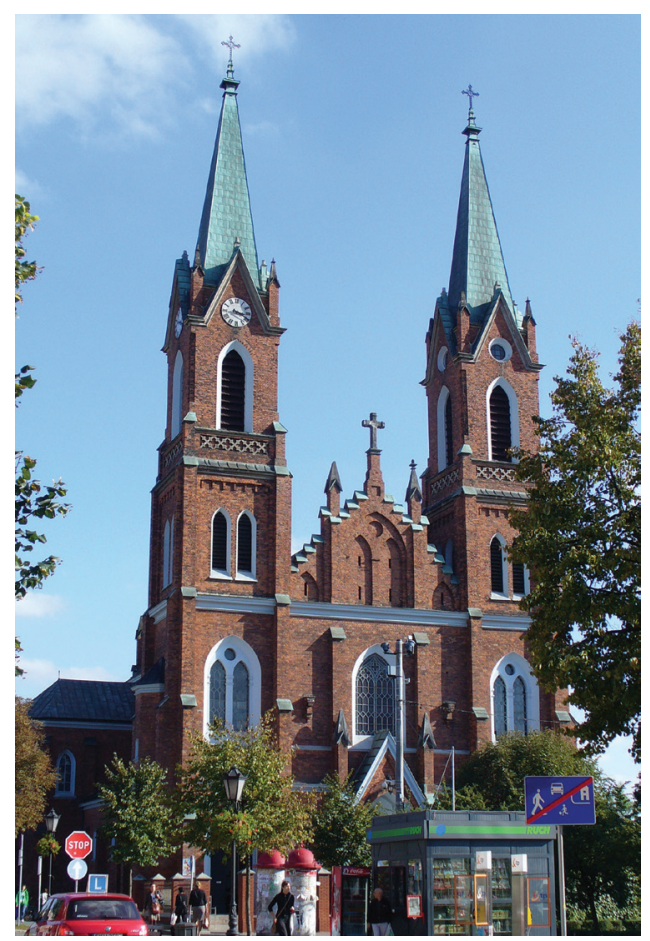

Il. 5. Kościół parafialny św. Wawrzyńca w Kutnie, 1884-1888, proj. Konstanty Wojciechowski, repr. za: Wikimedia Commons, 2012 w Kutnie, w którym pojawiły się elementy pokrewne formom katedry włocławskiej, tyle że w odpowiednio pomniejszonej skali ${ }^{41}$ (il. 5). Obiekt został zakomponowany jako trzynawowa bazylika z węższym jednonawowym prezbiterium zakończonym wielobocznie, $\mathrm{z}$ dwuwieżową fasadą i ceglanymi elewacjami. Bryłę urozmaicają boczne, zamknięte wielobocznie kaplice tworzące zarys krzyża. Warto podkreślić, że wieże fasady, nakryte ostrosłupowymi hełmami, są czworoboczne, o podstawie kwadratu, a projektowano je w momencie, gdy we Włocławku budowano wieże ośmioboczne według planów Stryjeńskiego.

W czasie, gdy Wojciechowski opracowywał własną wersję planów renowacji katedry włocławskiej, ogłoszono konkurs na projekt warszawskiego kościoła św. Floriana. Architekt wziął w nim udział, jednak jego propozycja nie zyskała przychylności jury. Przedstawione przez niego plany zakładały budowę świątyni w typie katedralnym, $\mathrm{z}$ bazylikowym korpusem o trzech nawach, między którymi usytuowano wąskie przejścia - quasi-nawy - poszerzające znacznie wnętrze (il. 6). Przestrzeń poszerzał także wydatny transept, którego ramiona kończą niskie, wieloboczne absydy. Fasadę zdobiły dwie bardzo smukłe wieże, w górnej partii ośmioboczne, z iglicowymi hełmami ${ }^{42}$ (il. 7). Była to rozbudowana wersja włocławskiej katedry, zachowująca - co warto podkreślić - ośmioboczny kształt wież zgodnie z koncepcją Stryjeńskiego.

Jeszcze w tym samym roku architekt miał okazję wykorzystać rozwiązania zastosowane we włocławskiej świątyni w innym znaczącym dziele, wprowadzając przy tym czworoboczną formę wież. Wykonał projekt nowego kościoła Wniebowzięcia Najświętszej Marii Panny w Łodzi, który postanowiono wybudować w miejscu drewnianego kościoła z XVIII w. ${ }^{43}$ (il. 8). Wojciechowski

41 Muzeum Narodowe w Warszawie, Rys. Pol. 15085; Archiwum Miejskie Warszawy, Rząd Gubernialny Warszawski, Referat Budowlany, sygn. 1265; zob. też Krzysztof Stefański, Konstanty i Jarosław Wojciechowscy - dwa pokolenia, dwie postawy wobec historyzmu, „Biuletyn Historii Sztuki” 2003, nr 1, s, 89-90.

42 Muzeum Narodowe w Warszawie, Rys. Pol. 15092.

43 Zygmunt Kiślański, Projekt kościoła katolickiego dla parafii Wniebowzięcia N. M. Panny $w$ Łodzi, „Przegląd Techniczny” 1886, nr 10, s. 238-239, tabl. XXIX; Krzysztof Stefański, 


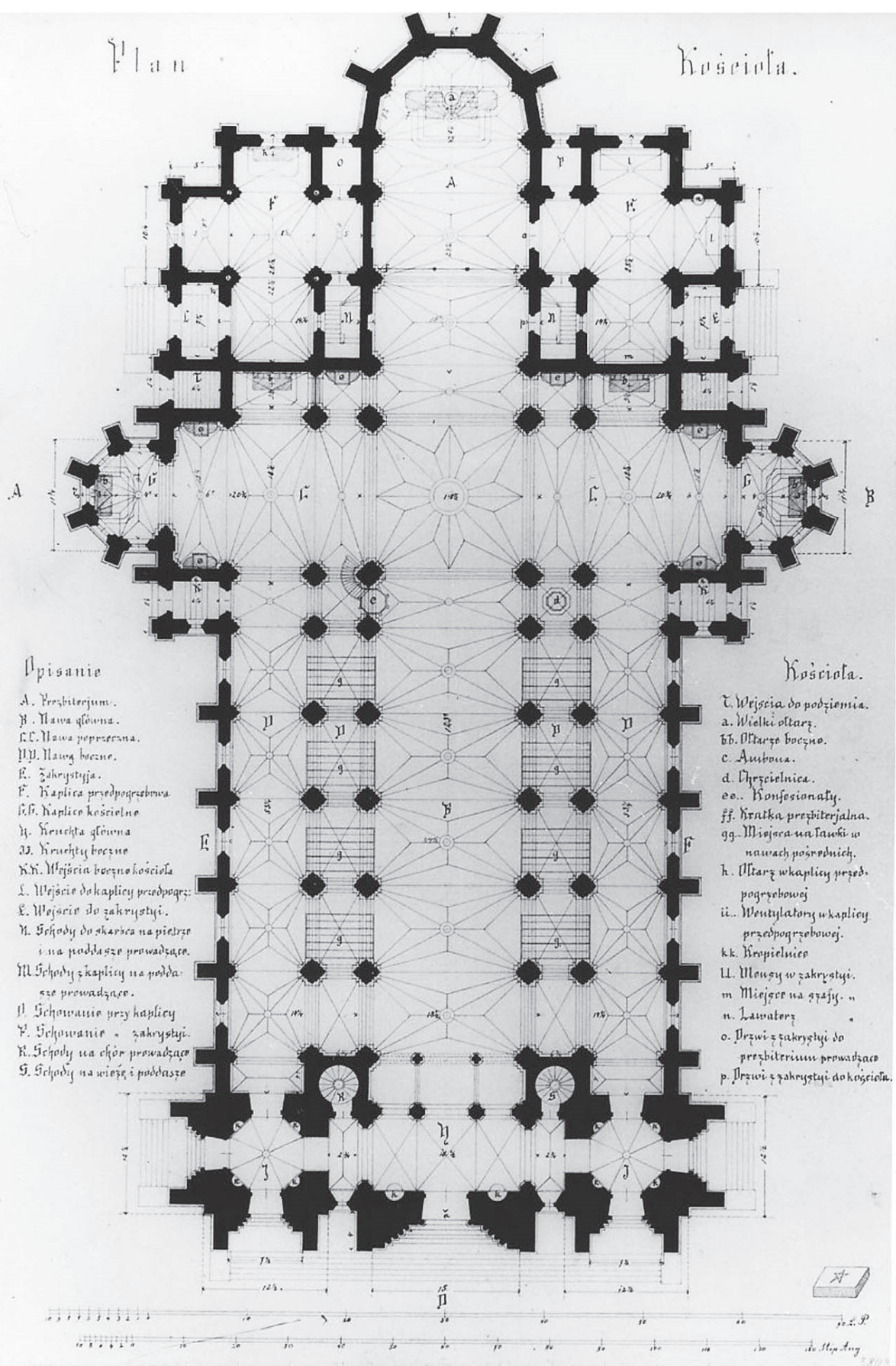

Il. 6. Konstanty Wojciechowski, projekt konkursowy kościoła św. Floriana w Warszawie, rzut poziomy, 1886, Muzeum Narodowe w Warszawie, Rys. Pol. 15092 


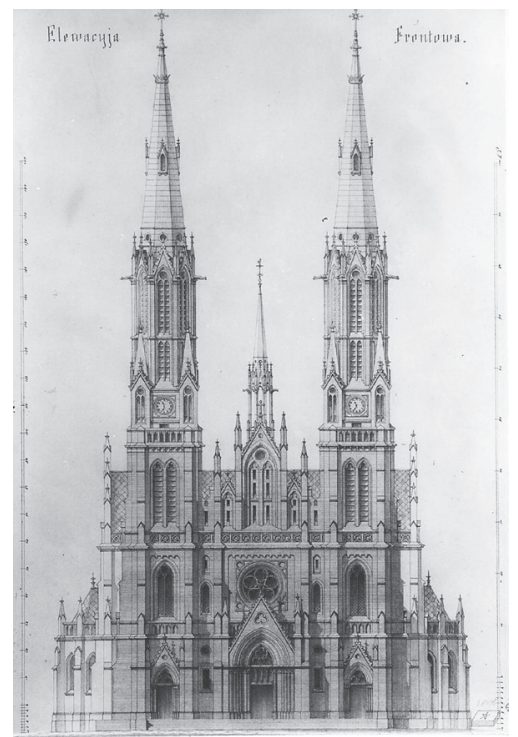

Il. 7. Konstanty Wojciechowski, projekt konkursowy kościoła św. Floriana w Warszawie, fasada, 1886, Muzeum Narodowe w Warszawie, Rys. Pol. 15092

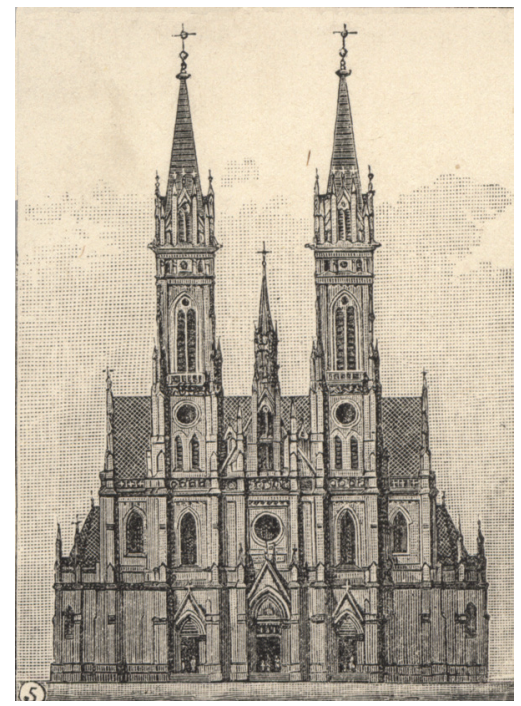

Il. 8. Konstanty Wojciechowski, projekt kościoła parafialnego pw. Wniebowzięcia NMP w Łodzi, fasada, 1886, repr. za: Jubiläums-Beilage zur „Lodzer Zeitung” 1863-1888, Łódź 1888 zastosował podobny schemat, tyle że w nieco skromniejszej wersji niż w projekcie konkursowym kościoła praskiego (z trzynawowym korpusem), choć znacznie bardziej okazały niż w Kutnie. Tuż po rozpoczęciu prac budowlanych informowano, że kościół będzie wzniesiony „w tak zwanym odcieniu wiślano-bałtyckim" ${ }^{4}$. W latach 1887-1897 powstała w Łodzi neogotycka świątynia o trójnawowym korpusie, rozszerzonym o boczne kaplice zastępujące transept, z zakończonym wielobocznie prezbiterium. W architekturze zewnętrznej zwraca uwagę bogaty ceglany detal, z okazałymi schodkowymi szczytami. W bryle świątyni dominuje wyniosła dwuwieżowa fasada, górująca (także dzięki położeniu na wzniesieniu) nad łódzkim Starym Miastem i całą północną częścią Łodzi. Czworoboczne wieże zakończono hełmami ostrosłupowymi, ujętymi u podstawy, z czterech stron, schodkowymi szczytami na wzór włocławski. Warto dodać, że kamień węgielny, po wymurowaniu fundamentów świątyni, poświęcił w maju 1888 r. ówczesny arcybiskup warszawski Wincenty Chościak-Popiel, wcześniejszy biskup włocławski i inicjator renowacji tamtejszej katedry ${ }^{45}$ (il. 9).

Łódzki kościół ma wszystkie istotne cechy katedry włocławskiej w formie, jaką nadała jej przebudowa Wojciechowskiego. Mamy tu do czynienia z ciekawym zjawiskiem twórczego sprzężenia wtórnego - warszawski architekt dokonuje regotycyzacji świątyni we Włocławku, nadając jej wyidealizowany kształt „gotyckiej katedry” o cechach, jakie według ówcześnie rozpowszechnionych poglądów miały być znamienne dla polskiego budownictwa kościelnego. Były to formy czerpiące $\mathrm{z}$ ceglanej architektury

Architektura sakralna Łodzi w okresie przemysłowego rozwoju miasta 1821-1914, Łódź 1995, s. 71-76.

${ }_{44}$ E.J., Kościoly katolickie w Łodzi, „Tygodnik Ilustrowany” 1888, nr 238, s. 364.

${ }^{45}$ Akt położenia kamienia węgielnego pod nowy kościót pod wezwaniem Wniebowzięcia N. M. P. w Łodzi, „Dziennik Łódzki” 1888, nr 112, s. 1; R. [Romuald Hube], Położenie kamienia wegielnego pod nowy kościót w Łodzi, „Kłosy” 1888, nr 1196, s. $342-343$. 
pomorskiej, ale zakorzenione na terenach północnych nizin polskich (Mazowsze, Kujawy, Wielkopolska) i zaakceptowane przez zwolenników koncepcji „stylu wiślano-bałtyckiego” jako polskie, rodzime ${ }^{46}$. Wspominany wyżej krytyk sztuki, Martynowski, stwierdzał, że styl ten jest „wytworem słowiańsko-polskim, wystawionym od czasu do czasu na silne wpływy Niemiec i krzyżactwa", i podkreślał znaczenie katedry we Włocławku, jako „najprzedniejszego pomnika architektury wiślano-bałtyckiej" ${ }^{37}$. Wojciechowski przekształcając włocławską świątynię, stworzył własny wzorzec „stylu wiślano-bałtyckiego”.

Wieloletnie prace restauracyjne przy katedrze we Włocławku pozwoliły warszawskie$\mathrm{mu}$ architektowi na dobre poznanie form ceglanego gotyku pomorskiego i wypracowanie charakterystycznego typu neogotyckiej dwuwieżowej świątyni o układzie bazylikowym, $z$ transeptem i ceglanymi elewacjami o bogatym detalu (szczyty, galerie, fryzy). Wypracowana przez niego wersja świątyni „wiślano-

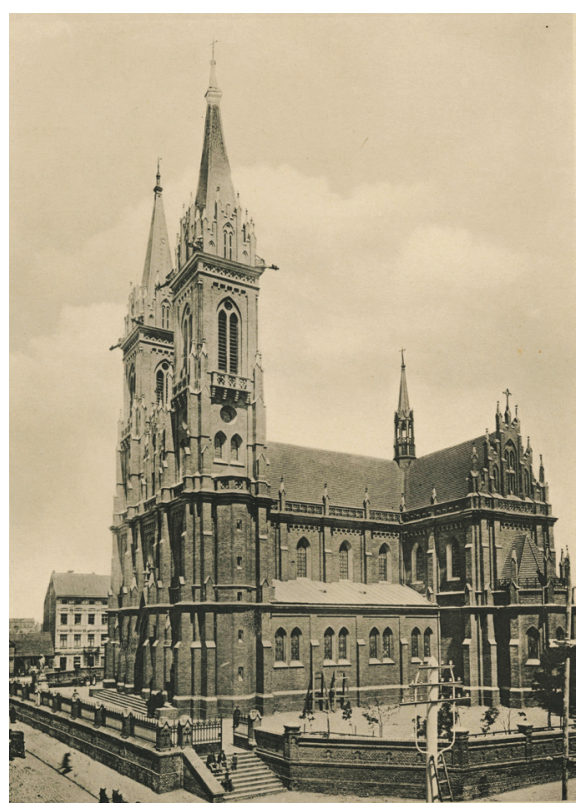

Il. 9. Kościół parafialny pw. Wniebowzięcia NMP w Łodzi, 1887-1897, repr. za: Bronisław Wilkoszewski, Widoki m. Łodzi, Łódź 1896 -bałtyckiej" była znacznie bliższa rodzimym wzorom niż formy zaproponowane przez Dziekońskiego w zwycięskim i zrealizowanym projekcie kościoła św. Floriana na Pradze oraz w innych licznych dziełach. Triumf Dziekońskiego w konkursie praskim sprawił, że Wojciechowski od lat osiemdziesiątych pozostawał w cieniu rywala pełniącego funkcje architekta archidiecezji warszawskiej i dysponującego w dziedzinie budownictwa kościelnego dużymi możliwościami, projektującego liczne ważne kościoły na prowincji i w stolicy ${ }^{48}$. Trzeba też zwrócić uwagę na twórczość innego warszawskiego architekta, Szyllera, który próbował (ale nieco później) wypracować własną odmianę neogotyckich form „stylu wiślano-bałtyckiego”, wprowadzając w budowanych przez siebie kościołach bardziej urozmaicone motywy, dążąc do asymetrii i uzyskania większej malowniczości w sylwetce kościoła, co można odczytać jako silniejsze nawiązanie do budownictwa krakowskiego. Założenia te realizowały kościoły w Dłutowie (1894-1897) ${ }^{49}$, Chełmicy Dużej (1905-1917), Charłupi Małej (1907-1916), Baboszewie (1910-1914) i Druskiennikach (1912-1931), a także

46 Majdowski, O pogladach na styl..., s. 49 n.; Stefański, Polska architektura..., s. 31-36.

7 Martynowski, $O$ stylu..., s. 3.

48 Majdowski, Budownictwo kościelne..., passim.

49 „Przegląd Techniczny” 1894, z. 3, s. 67, tabl. XII; Stefański, Polska architektura...., s. 56; Omilanowska, Architekt Stefan Szyller..., s. 158, 241-244. 


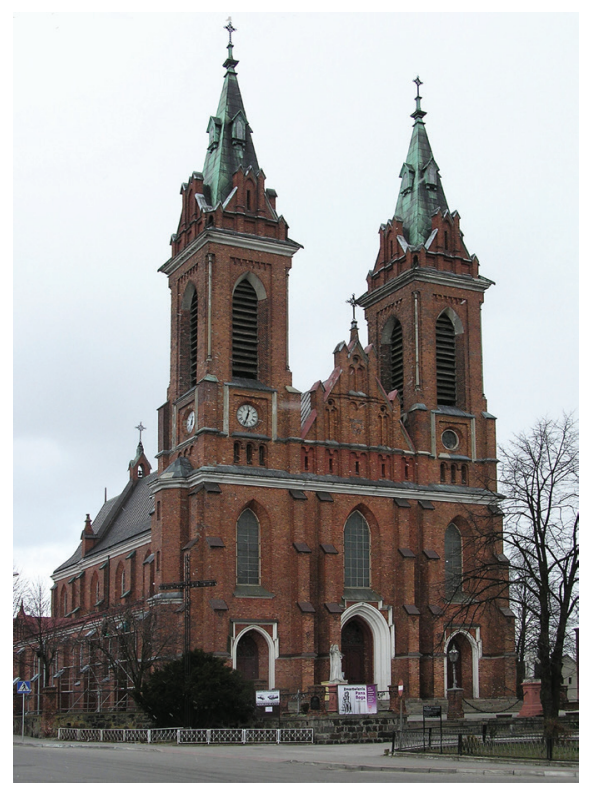

Il. 10. Kościół parafialny św. Wawrzyńca w Milejowie, 1897-1902, proj. Konstanty Wojciechowski, fot. K. Stefański

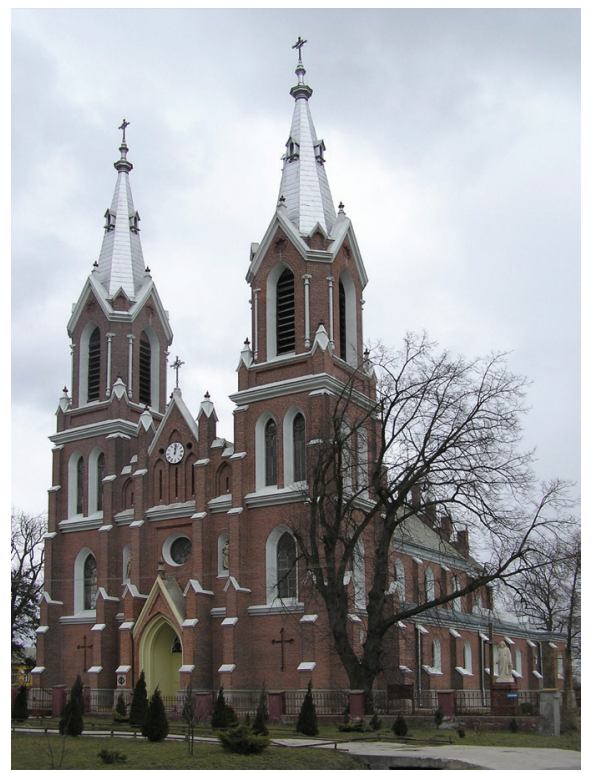

Il. 11. Kościół parafialny św. Wawrzyńca w Gorzkowicach, 1896-1898, proj. Konstanty Wojciechowski, fot. K. Stefański projekt kościoła w Ciepielowie ${ }^{50}$. W późniejszym okresie architekt silniej skłaniał się w stronę motywów renesansowo-barokowych.

Wojciechowski od lat osiemdziesiątych XIX w. aktywnie działał na terenie diecezji włocławskiej, obejmującej zachodnią część Królestwa Polskiego, a na południu sięgającej Górnego Śląska. Przez wiele lat nie miał jednak okazji, poza budową kościoła w Łodzi, do stworzenia wybitniejszego projektu. W latach dziewięćdziesiątych XIX w. i w pierwszej dekadzie XX w. wybudował liczne świątynie wiejskie i małomiasteczkowe (m.in. Milejów, Gorzkowice, Kompina, Zduny). Wypracowany we Włocławku i powtórzony z powodzeniem w Łodzi typ neogotyckiej ceglanej świątyni dostosowywał do skromniejszych możliwości finansowych małych parafii. W wiejskich kościołach w Gorzkowicach (1896-1898, il. 10) i w Milejowie koło Piotrkowa Trybunalskiego (1897-1902, il. 11) oraz w Kompinie nieopodal Łowicza (1897-1900) redukował formę budowli, rezygnując z bocznych kaplic i ograniczając detal $^{51}$. Dominującym akcentem są dwuwieżowe fasady, skromniejsze w skali. Podobne rozwiązanie pojawia się także w zrealizowanym przez niego kościele w Starych Wasiliszkach w pobliżu Grodna (1897-1903), a więc poza granicami Królestwa ${ }^{52}$. W większej skali rozwiązanie to pojawiło się w projekcie kościoła w Turku. Architekt zaczął opracowywać go w 1904 r., a po jego śmierci projekt dokończył syn Jarosław Wojciechowski, który zmienił fasadę świątyni, wprowadzając asymetrię kompozycji ${ }^{53}$. Niekiedy Konstanty Wojciechowski

50 Objaśnienia tablic, „Architekt” 1905, z.9, szp. 138-144, tabl. 45; Stefański, Polska architektura..., s. 96-100; Omilanowska, Architekt Stefan Szyller..., s. 158-161, 330-332, 338-339, 380-383, 385-387.

51 Stefański, Konstanty i Jarosław Wojciechowscy..., s. 90.

52 Muzeum Narodowe w Warszawie, Rys. Pol. 15051; Poświęcenie kościoła w Wasiliszkach, „Życie i Sztuka” (ilustrowany dodatek do „Kraju”) 1902, nr 41, s. 6.

53 Muzeum Narodowe w Warszawie, Rys. Pol. 15052; Archiwum Państwowe w Łodzi [dalej: APŁ], Rząd 
próbował odchodzić od powyższego schematu, stosując odmienne rozwiązania. W kościele w Zdunach koło Łowicza dwuwieżowa fasada została zastąpiona układem trzech wież z dominującą wysokością środkową ${ }^{54}$.

Spośród prac Wojciechowskiego na uwagę zasługuje kościół parafialny w Opatówku koło Kalisza. Była to przebudowa wcześniejszej świątyni, której forma została ukształtowana około 1820 r. z inicjatywy ówczesnego właściciela miejscowości, namiestnika generała Józefa Zajączka. Dawny kościół pochodzący z XV w. przekształcono wówczas w duchu wczesnego romantycznego neogotyku, najprawdopodobniej według planu Chrystiana Piotra Aignera ${ }^{55}$. Korpus otoczono podcieniem $\mathrm{z}$ ostrołucznymi arkadami, ujmującymi boczne kaplice (w jednej z nich znalazł się nagrobek generała). Przystępując do rozbudowy kościoła, Wojciechowski uszanował wcześniej istniejącą formę, w ciekawy sposób wtapiając ostrołuczne arkady w zewnętrzne ściany dobudowanych naw bocznych. Jednocześnie odwrócił orientację kościoła, sytuując dwuwieżową fasadę w miejscu dawnej absydy ołtarzowej, a wcześniejszą wieżę frontową pozostawiając za nowo uformowaną częścią prezbiterialną ${ }^{56}$. Prace wykonano w latach 1905-1912. Zachowując elementy starej struktury, architekt nadał całości formę zgodną z duchem „stylu wiślano-bałtyckiego”.

Na początku XX w. Wojciechowski otrzymał szansę zrealizowania dużej neogotyckiej świątyni w prawdziwie „katedralnym” stylu, która mogła być doskonałą egzemplifikacją autorskiej wizji „stylu wiślano-bałtyckiego”. Była to budowa kościoła Świętej Rodziny w Częstochowie. Inicjatywa wzniesienia budowli wiązała się z nadziejami na utworzenie odrębnej diecezji częstochowskiej, co ziściło się jednak dopiero w latach Polski niepodległej. Wiara w powstanie diecezji częstochowskiej u progu XX w. kazała władzom kościelnym zamówić u Wojciechowskiego projekt kościoła znacznych rozmiarów. W 1901 r. architekt wykonał plany neogotyckiej „katedry”, po raz kolejny nawiązując do form znanych z Włocławka. Obiektowi nadał kształt trójnawowej bazyliki na planie krzyża łacińskiego, z wydatnym transeptem i jednonawowym, wielobocznie zamkniętym prezbiterium z obejściem. Fasadę miały ozdobić dwie wysokie wieże $\mathrm{e}^{57}$. W następnym roku ruszyły prace, ale architekt nie doczekał ich ukończenia. Budowa świątyni trwała aż do lat pięćdziesiątych XX w. ${ }^{58}$, a górne części wież wraz z hełmami powstały dopiero w 1998 r. ${ }^{59}$

Gubernialny Kaliski, Wydział Administracyjny, sygn. 2328; Budowa kościoła w Turku, „Kronika Diecezji Kujawsko-Kaliskiej” 1912, nr 2, s. 56-62.

54 Stefański, Polska architektura..., s. 54.

55 Kościół w Opatówku, „Tygodnik Ilustrowany” 1904, nr 44, s. 849; zob. Wojciech Bałus, Piotr Krasny, Kościół parafialny w Wielączy, „Miscellanea Łódzkie” 1996, nr 1, s. 36.

56 Muzeum Narodowe w Warszawie, Rys. Pol. 15063.

57 APŁ, Rząd Gubernialny Piotrowski, Wydział Budowlany, sygn. 18469.

58 Obiekt oddano do użytkowania w 1927 r., a w 1950 r. poświęcono, zob. Prace nad urzadzaniem katedry częstochowskiej w latach 1951-1956, „Częstochowskie Wiadomości Diecezjalne” 1957, nr 11, s. 450-452.

59 Ich projekt wykonał prof. Edmund Małachowicz z Politechniki Wrocławskiej, jedynie luźno nawiązując do pierwotnej koncepcji Wojciechowskiego. 


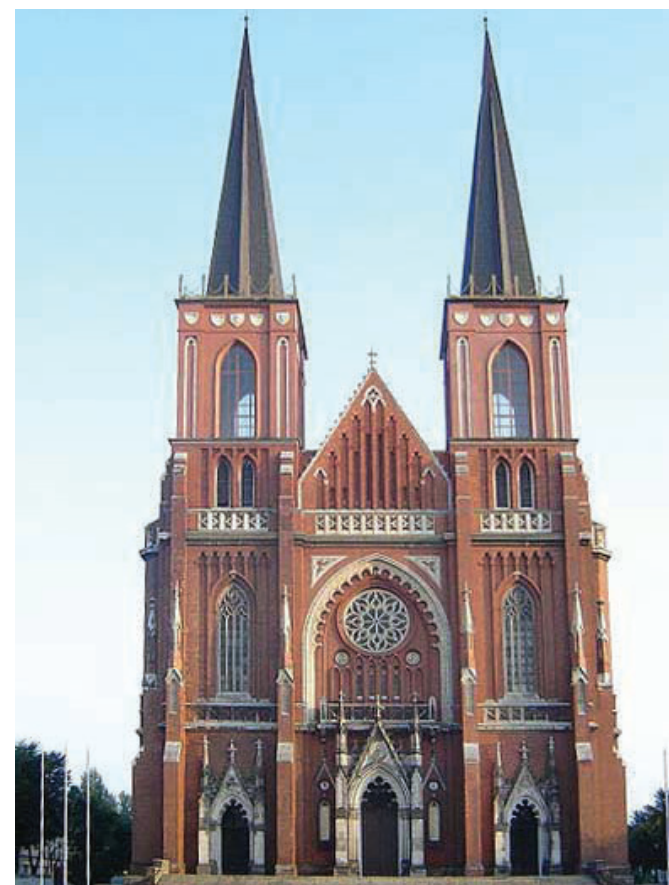

Il. 12. Katedra pw. Świętej Rodziny w Częstochowie, 1901-1950, proj. Konstanty Wojciechowski, fot. K. Stefański
Choć obiekt ukończono blisko dziewięćdziesiąt lat po śmierci architekta, zmarłego w 1910 r., w całkowicie innej już epoce, a ważny element sylwetki budowli, jakim są zwieńczenia wież, przekształcono, to był on ziszczeniem wizji Wojciechowskiego na temat polskiego stylu narodowego w budownictwie kościelnym. Odstępstwem od innych dzieł twórcy wzniesionych w „stylu wiślano-bałtyckim” jest bogate wykorzystanie kamienia $\mathrm{w}$ fasadzie, urozmaicające ceglaną architekturę świątyni, a także łuki odporowe, których stosowania wcześniej unikał (il. 12).

Wojciechowski należy do najbardziej znaczących postaci polskiego życia architektonicznego na przełomie XIX i XX w., a w jego działalności główną rolę odegrała architektura sakralna. Momentem decydującym o jego twórczej drodze było podjęcie w latach osiemdziesiątych XIX w. prac restauracyjnych przy katedrze

we Włocławku. Pozwoliły mu one na dobre poznanie form architektury gotyckiej północnych ziem polskich, pozostających pod wpływem gotyku Pobrzeża Bałtyckiego, i wykorzystanie ich w swojej dalszej twórczości. Zbiegło się to czasowo z popularyzowaniem idei „stylu wiślano-bałtyckiego” jako polskiego stylu narodowego. Efektem były liczne kościoły neogotyckie jego autorstwa, w których wykształcił własną odmianę form „wiślano-bałtyckich”, czerpiąc z rozwiązań, jakie zastosował we włocławskiej świątyni. Sprawia to, że katedrę we Włocławku należy uznać za budowlę o doniosłym znaczeniu dla ukształtowania się architektury sakralnej ziem polskich zaboru rosyjskiego na przełomie XIX i XX w.

\section{Bibliografia}

Bałus Wojciech, Krasny Piotr, Kościół parafialny w Wielączy, „Miscellanea Łódzkie” 1996, nr 1 (15), s. 34-36.

Błażejewska Anna, Pilecka Elżbieta, Dzieje sztuki [w:] Dzieje diecezji włocławskiej, t. 1, Średniowiecze, red. Andrzej Radzimiński, Włocławek 2008.

Długosz Jan, Roczniki, czyli kroniki sławnego Królestwa Polskiego, ks. 9, przeł. J. Mrukówna, Warszawa 1975. 
Essenwein August, Die mittelalterlichen Kunstdenkmale der Stadt Krakau, Graz 1866.

Frycz Jerzy, Neogotyk i restauracja zabytków w Polsce [w:] Sztuka 2. połowy XIX wieku.

Materiały Sesji Stowarzyszenia Historyków Sztuki. Łódź, listopad 1971, Warszawa 1973, s. 173-182.

Frycz Jerzy, Restauracja i konserwacja zabytków architektury w Polsce w latach 1795-1918, Warszawa 1975.

Hube Romuald, Kościół parafialny stary i nowy w Radomsku, Warszawa 1876.

Jung Kazimierz ks., Katedra Włocławska. Krótki rys historyczny m. Włocławka, katedry i Diecezyi Włocławskiej, Włocławek 1900.

Lewandowski Dariusz, Regotycyzacja katedry we Włocławku w końcu XIX wieku, „Studia Włocławskie" 2002, t. 5, s. 366-378.

Łoza Stanisław, Architekci i budowniczowie w Polsce, Warszawa 1956.

Machowski Marek, Włodarek Andrzej, Włocławek. Kościół katedralny pw. Panny Marii [w:] Architektura gotycka w Polsce, t. 2, Katalog zabytków, red. Teresa Mroczko, Mariusz Arszyński, Warszawa 1995 (Dzieje sztuki polskiej, 2).

Majdowski Andrzej, Budownictwo kościelne w twórczości projektowej Józefa Piusa Dziekońskiego (1844-1927), Warszawa 1995.

Majdowski Andrzej, Nurt narodowy w architekturze sakralnej Królestwa Polskiego od drugiej polowy XIX wieku. Wybrane problemy, „Nasza Przeszłość. Studia z dziejów Kościoła i kultury katolickiej w Polsce” 1985, t. 64, s. 5-55.

Majdowski Andrzej, Studia z historii architektury sakralnej w Królestwie Polskim, Warszawa 1993.

Matuszewski Karol, O architekturze u obcych i u nas. Uwagi ze stanowiska estetycznego, „Biblioteka Warszawska” 1881, t. 3, s. 75-93, 231-245, 382-405.

Miłobędzki Adam, Zarys dziejów architektury w Polsce, Warszawa 1978.

Morawski Michał ks., Monografia Włocławka (Włocławia), Włocławek 1933.

Olszewski Andrzej K., Przegląd koncepcji stylu narodowego w teorii architektury polskiej przełomu XIX i XX wieku, „Sztuka i Krytyka. Materiały do studiów i dyskusji z zakresu teorii i historii sztuki, krytyki artystycznej oraz badań nad sztuką" 1956, nr 3-4, s. 275-372.

Omilanowska Małgorzata, Architekt Stefan Szyller 1857-1933, Warszawa 2008.

Pajor Piotr, Utzig Joanna, „Godny miana katedry. O genezie formy architektonicznej kościoła katedralnego we Włocławku”, „Folia Historiae Artium. Seria Nowa” 2016, t. 14 , s. 17-34.

Skibiński Szczęsny, Polskie katedry gotyckie, Poznań 1996.

Stefański Krzysztof, Architektura sakralna Łodzi w okresie przemysłowego rozwoju miasta 1821-1914, Łódź 1995.

Stefański Krzysztof, Konstanty i Jarosław Wojciechowscy - dwa pokolenia, dwie postawy wobec historyzmu, „Biuletyn Historii Sztuki” 2003, nr 1, s. 83-110.

Stefański Krzysztof, Polska architektura sakralna w poszukiwaniu stylu narodowego, Łódź 2000.

Utzig Joanna, Witraże w katedrze we Włocławku w kontekście stylu malarstwa południowoniemieckiego pierwszej połowy XIV wieku, „Folia Historiae Artium. Seria Nowa” 2015, t. 13 , s. 5-32.

Wierzbicka Bożena, Franciszek Ksawery Martynowski 1848-1896. Polihistor, teoretyk restauracji zabytków, krytyk sztuki, Warszawa 1998. 
The Włocławek Cathedral dedicated to the Assumption of the Blessed Virgin Mary is one of the most important Gothic churches in the lowlands of northern Poland. However, overshadowed by the Cathedrals in Poznan and Gniezno, it is considered a building that is more modest in scale and less artistically valuable. An important issue related to the history of the church is its restoration that was carried out in the last two decades o the 19th century, initially according to the plans of Tadeusz Stryjeński from Cracow and then led by the Warsaw architect Konstanty Wojciechowski (1841-1910). Wojciechowski re-Gothycized the building, giving it a 'cathedral' form featuring a magnificent façade with two high towers. These works coincided with the growing popularity of the idea of the 'Vistula-Baltic Gothic' as the Polish national style in church construction. The Warsaw architect used the forms of the cathedral he rebuilt to develop his own vision of the church in the 'Vistula-Baltic style', competitive to the solutions used by Józef Dziekoński. The incarnation of this vision was the church of the Assumption of the Virgin Mary in Łódź, followed by a series of smaller buildings erected in villages and in small towns within the Russian partition, in which the architect repeated his pattern on a smaller or larger scale. The culmination of Wojciechowski's creative path was the Church of the Holy Family in Częstochowa (the current Cathedral), built from 1901. 